\title{
The Competence of Intention in Moderating the Influence of Taxation Knowledge, Moral Obligation and Service Quality to Taxpayer's Compliance in Cooperative in Bali, Indonesia
}

\author{
Ni Made Dwi Ratnadi and I Nyoman Wijana Asmara Putra \\ Department of Accounting, Faculty of Economics and Business, Udayana University, Indonesia
}

\begin{abstract}
This study aims to test the competence of intention in moderating the influence of taxation knowledge, moral obligation and service quality to taxpayer's compliance behavior in cooperative. Respondents are 91 cooperative managers who have provincial level work areas in Bali Province and already have taxpayer identification number. Data are obtained by survey method through questionnaires distribution and analyzed by moderation regression. The results of the analysis indicate that the intention is unable to moderate the influence of taxation knowledge on taxpayer's compliance behavior. The intention is also not able to moderate the effect of moral obligations to taxpayer's compliance behavior. However, the intention is capable to moderate the significance of tax service quality on taxpayer's compliance behavior.
\end{abstract}

Keywords: Taxpayer's compliance, Moral obligation, Service quality, Intention

DOI: $10.7176 /$ RJFA/10-24-20

Publication date: December $31^{\text {st }} 2019$

\section{Introduction}

Taxes have decisive role in the activity of the country, especially in the implementation of development, because tax is one of many sources of country income to finance all expenditures, including development expenditure. Tax is the main source of country income in Indonesia. Without taxes, most of the country's activities are difficult to be executed. The use of tax money covers from employee expenditure to financing various development projects. The construction of public facilities such as roads, bridges, schools, hospitals, puskesmas (community health center) and police stations are funded by tax-deductible money. Tax money is also managed for financing in order to provide a sense of security for all levels of society. Every citizen, from the time of birth to death, has benefit from the facilities or services of the government, all of which are financed with money derived from taxes. Taxes are used to subsidize the goods that people really need and also pay the country's debt abroad. Taxes are also used to help Small and Medium Micro Enterprises (SMEs) both in terms of coaching and capital. Thus, it is clear that the role of tax income for a country become very dominant in supporting the policy of the wheels of government and development fund.

In addition to the function of budgeter, tax also performs the income redistribution function of people with higher economic capabilities to the people with lower capacities. Therefore, the taxpayers' compliance level in performing their tax obligations properly and correctly are an absolute requirement for achieving income redistribution function (Erwin, 2009). Tax officer should supervise the taxpayer, because the tax system in Indonesia is self-assessed, in which the taxpayer is given the trust to calculate, pay and report the amount of tax payable.

Low taxpayer's compliance has correlation with the insignificant realization of tax income and tax ratio in Indonesia (Widayanti and Nurlis, 2010). This happens because the taxpayers do not accomplish their obligations as they should. Compliance issues can be seen in terms of public finance, law enforcement, organizational structure, ethics or combine of all these problems. Taxpayer compliance in fulfilling the tax obligations affects tax income in Indonesia (Rustiyaningsih, 2011). Taxpayer compliance behavior can be explained by the theory of attribution. Behavior of a person is influenced by internal and external factors. Internal factors that can affect taxpayer's compliance behavior namely understanding the existing of tax laws in Indonesia and the moral obligations of taxpayer. Research by Siregar, et al. (2012), Muarif (2013) and Adiasa (2013) concluded that there is an effect on taxpayer's compliance by the knowledge of tax laws. In contrast, Hardiningsih and Yuliawati (2011) and Pranadata (2014) proved that the knowledge of tax laws does not affect the willingness of taxpayers to do their obligation. Moral duty is another means of maximizing taxpayer's compliance. Ho (2004) revealed 
that the taxpayer's compliance level becomes higher when the taxpayer has a stronger moral obligation.

Moreover, the quality of tax service is an external factor that affect taxpayer's compliance behavior. Hardiningsih and Yulianawati (2011), Zulaikha (2012), Siregar, et al. (2012), Fuadi and Mangoting (2013) and Murti, et al. (2014) confirmed that taxpayer's compliance can be increased by raising public knowledge to fulfill the responsibility of paying taxes and providing good, friendly, fair and decisive service. However, Zulaikha and Nugroho (2012), Pranadata (2014), Metia (2015) and Maulana (2015) found that the quality of tax service has no impact on taxpayer's compliance.

Previous research showed inconsistent results. The contradiction is probably caused by the psychological aspect of the taxpayer that can change the behavior of the taxpayer. The specific behavior of the person can be analyzed by the theory of planned behavior. The taxpayer's specific behavior is action to not obedient with tax regulations that is influenced by intention. Ajzen (1991) stated that attitudes toward noncompliance influence the intention of disobedience. Mustikasari (2007) explained that the behavior of noncompliance is based on the intention to disobey taxes.

\subsection{Aim of Study}

This study aims to empirically test the ability of taxpayer intention to moderate the influence of taxation knowledge on taxpayer's compliance, the ability of taxpayer intention to moderate the effect of moral obligation on taxpayer's compliance and the ability of taxpayer intention to moderate the significance of service quality on taxpayer's compliance.

\subsection{Significance of Study}

This research contributes to confirm theory of attribution concerning taxpayer's compliance behavior and theory of planned behavior that are applied to cooperative taxpayers. Cooperative as one of the government-recognized institutions becomes part of the object of country's regulations and legislation. As the consequence, the cooperative must contribute to the country in the form of tax deposit. Cooperative in general often experience problems related to tax obligation.

\section{Literature Review and Hypotheses Development}

\subsection{Theory of Attribution}

Theory of attribution views the individual as an amateur psychologist who tries to understand the causes of the various events encountered. The theory that is developed by Heider (1958) is a theory that explained about the person's behavior and understanding the reaction to events around them (Mayer, et al., 1995). A person's behavior is related to his/her attitude and characteristics. This theory also stated that by looking at the person's behavior, it can be known their attitudes or characteristics. Furthermore, it may predict the behavior of a person in deal with certain situations.

There are two behavior of a person in social perception, namely dispositional and situational attribution. Dispositional attribution is internal matter that refers to aspects of individual behavior that exist in a person, such as personality, self-perception, ability and motivation. Situational attribution is external matter that refers to the surrounding environment that affect behavior, for example social conditions, social values and views of society.

Behavior that is caused internally is believed to be under the personal control of the individual itself or from internal factors. Meanwhile, behavior that is influenced from outside or from external factors are equipment or social influences from others. As a result, the individual is forced to behave in a situation (Robbins, 1999). In accordance with the theory of attribution, taxpayer's compliance can be determined by the internal strength of the taxpayer's understanding of existing tax regulations and external strength, namely the moral obligation of cooperatives management to their members.

\subsection{Theory of Planned Behavior}

This theory defines a framework for studying attitudes toward behavior. The most important determinant of a person's behavior is intention to behave. The individual's intention to represent behavior is a combination of attitudes to display certain behaviors and subjective norms.

Theory of planned behavior is based on the assumption that human beings are rational and use information systematically. Individuals think about the implications of their actions before they decide to do or not to do behavioral beliefs. Ajzen and Fishbein (1969) and Bobek, et al. (2003) affirmed that intention is the behavior of two main determinants: attitude toward behavior and subjective norm of behavior. Attitude is positive or 
negative belief to demonstrate a particular behavior. Individuals intend to represent a certain behavior when they consider it positively. Attitude is determined by individual beliefs about the consequences of performing behavioral beliefs.

The behavior featured by the individual arises because of the intention to behave. Behavioral intentions are triggered by three factors (Ajzen, 1991), namely:

a. Behavioral belief, which is the individual's belief in outcome of the behavior and evaluation of the results (beliefs strength and outcome evaluation).

b. Normative belief, which is the belief about the normative expectations of others and the motivation to fulfill those expectations (normative beliefs and motivation to comply).

c. Control belief, which is the belief concerning the existence of aspects that support or inhibit the behavior that is performed (control belief) and perception about how strong the aspects that support and inhibit their behavior (perceived power).

Barriers that may arise when the behavior is performed can come from within themselves or the environment. Ajzen and Fishbein (1969) explained that intention is cognitive and conative representation of the individual's readiness to display a behavior. Intention is the determinant and disposition of behavior until the individual has the right opportunity and time to perform the behavior significantly. The better the intention possessed by a person leads to better behavior to obey the taxes (Metia, 2015).

\subsection{Hypotheses Development}

Taxation knowledge is the process of transforming the attitude and behavior of taxpayers in order to developing the people through teaching and training. Theory of planned behavior is used to examine the more specific behavior, i.e. behavior to not obey the provisions of taxation. Ajzen and Fishbein (1969) expressed intentions as a cognitive and conative representation of the individual's readiness to display a behavior. Intention is the determinant and disposition of behavior, so that the individual has the right opportunity and time to display the behavior to others. Mustikasari (2007) concluded that taxpayers who have attitude of tax noncompliance result in high intentions of tax noncompliance. Hidayat and Nugroho (2010) stated that the behavior of tax noncompliance is based on the intention to disobey the taxes. Therefore, the hypothesis is defined as follows.

$\mathrm{H}_{1}$ : Taxpayer's intentions strengthen the influence of taxation knowledge on taxpayer's compliance

Moral obligation is the norm that the individual has in experiencing certain things, such as ethics and principles of life (Ajzen, 2002). Pranata (2015), Hardiningsih, et al. (2011) and Razman (2015) found that the moral obligation has positive effect on corporate taxpayer reporting at West Denpasar tax office. This means that the higher the morality of taxpayers affect the increase of tax compliance. Richardson (2006) and Mustikasari (2007) revealed that moral obligation has positive impact on corporate taxpayer's compliance. If the corporate taxpayer has high moral obligation then the tax compliance is increased. Therefore, the hypothesis is defined as follows.

$\mathrm{H}_{2}$ : Taxpayer's intentions strengthen the influence of moral obligation on taxpayer's compliance

Quality service can improve taxpayer's compliance in realizing tax obligation (Winerungan, 2013). The small compliance of taxpayers to tax laws is caused by the low quality of service by the tax officers (Fuadi and Mangoting, 2013). Hardiningsih and Yulianawati (2011), Siregar, et al. (2012) and Murti, et al. (2014) proved that the quality of tax service has significant effect on taxpayer's compliance. Ajzen (1991), Hanno and Violette (1996) and Handayani, et al. (2011) found that attitudes towards tax noncompliance influence the intention of tax noncompliance. Therefore, the hypothesis is defined as follows.

$\mathrm{H}_{3}$ : Taxpayer's intentions strengthen the influence of quality of tax service on taxpayer's compliance

\section{Research Methods}

\subsection{Sample and Population}

The population of this research is all cooperatives which have operational area cover the Bali Province. The sample is determined by nonprobability sampling method with saturated sample technique. All cooperatives that have taxpayer identification number are given the questionnaires. Research respondents are cooperative managers or managements as the party in charge who manage the cooperatives.

\subsection{Data Source}

The data used in this study are primary data sourced from the results of respondents' answers to the 
questionnaire that are distributed before. Respondents' answers are measured with 5-point likert scale.

\subsection{Operational Definition of Variables}

There are three types of variables analyzed in this research. Taxpayer compliance as dependent variable. Independent variable consisting of service quality, moral obligation and knowledge of taxpayer. Finally, taxpayer intention is moderating variable. The following sections describe the operational definitions and indicators of each of these variables.

Taxation knowledge is the understanding and comprehension of taxation general provisions covering the way of submitting the tax return, payment, payment place, penalty and deadline of payment or reporting the tax return. Knowledge of taxation according to Handayani, et al. (2011) can be measured by four indicators below.

a. Knowledge and understanding of sanctions in case of taxation violation.

b. Knowledge and understanding of cooperative tax obligations and tax rates.

c. How to acquire knowledge and understanding of tax rules through socialization.

d. How to gain knowledge and understanding of tax rules through training.

Moral obligations of the taxpayers are ethics, principles of life, feelings of guilt that are perceived if not fulfilling voluntary taxation obligations that can be attributed to the accomplishment of tax obligations.

Quality of tax service is tested using five dimensions according to Parasuraman, et al (1998), which acknowledged that to measure the satisfaction of service, the service quality instrument is accepted. There are five dimensions in the instrument, which can be explained below.

a. Reliability is the fulfillment of immediate and satisfactory service by tax officials. Reliability includes the ability to deliver services accurately as promised.

b. Responsiveness is the ability of employee to help taxpayer to provide service quickly in accordance with the desired by the taxpayer. The activeness of service delivery is quickly responsive.

c. Assurance means that the tax officer has the knowledge and ability to serve the taxpayer with friendly and polite attitude.

d. Empathy is the attention given by the tax officer individually to the taxpayer and understand the information required by the taxpayer.

e. Physical evidence (tangibles) is the attention on goods or facilities concerning the appearance of physical facilities, equipment, personal and communication tools.

Taxpayer's intention. Intention is the tendency of the taxpayer to perform obedient behavior or tax noncompliance. Behavioral intentions are measured by three indicators, which is in accordance with the studies conducted by Ajzen (1991), Mustikasari (2007) and Hidayat and Nugroho (2010) as follows.

a. Behavioral belief is individual belief about the outcome of behavior and evaluation of the results (beliefs strength and outcome evaluation).

b. Normative belief is acceptance in relation to the normative expectations of others and motivation to meet those expectations (normative beliefs and motivation to comply).

c. Control belief is expectation concerning the existence of circumstances that support or inhibit the behaviors displayed and perceptions about how strongly supports and inhibits the behaviors (perceived power).

Taxpayer compliance is an act of the taxpayer in the fulfillment of tax obligations in line with the provisions of the laws and regulation of taxation implementation in a country. Taxpayer compliance behavior is measured using indicators coherent with the regulation in Indonesia (Regulation of the Minister of Finance article 3, No. 192/PMK.03/2007 Jo. No.74/PMK.03/2012) which affirms that there are several conditions to be stipulated as compulsory taxpayers, as follows.

a. Punctuality in submitting the tax return.

b. Should no tax arrears for all types of taxes that become his obligations.

c. The annual financial statements have been audited by certified public accountant or government financial oversight body with unqualified opinion.

d. Should never been convicted of criminal offenses in the field of taxation based on the court decisions that have had permanent legal force within the last five years. 


\subsection{Data Analysis Technique}

The analysis technique used is Moderated Regression Analysis (MRA) with the following formula.

$T C=\alpha+\beta_{1} T K+\beta_{2} M O+\beta_{3} S Q+\beta_{4} T I+\beta_{5} T K * T I+\beta_{6} M O * T I+\beta_{7} S Q * T I+\varepsilon$

Notation

$\begin{array}{ll}\text { TC } & \text { : Taxpayer's Compliance } \\ \text { TK } & : \text { Taxation Knowledge } \\ \text { MO } & : \text { Moral Obligation } \\ \text { SQ } & : \text { Service Quality } \\ \text { TI } & : \text { Taxpayer's Intention } \\ \beta_{1}-\beta_{7} & : \text { Coefficients } \\ \alpha & : \text { Constants }\end{array}$

Prior to hypothesis testing, classical assumption test is conducted in order to determine if there are any discrepancies of the assumption. Requirement of linear regression analysis based on Ordinary Least Square (OLS). The classical assumption test performed are normality and heteroskedasticity test. Normality test is aimed to test whether the disruptive or residual variable is normally distributed, which is tested by Kolmogorov Smirnov. Heteroskedasticity test is intended to test whether in the regression model there is variance inequality of the residual or observation to another observation, which is tested by the Glejser Test.

\section{Results and Discussions}

\subsection{Description of Respondents}

Cooperatives that operate at the level of Bali Province as many as 170 units, whose 9 units are not active, leaving the remaining 161 units are still active. Questionnaires are distributed directly to each cooperative. Before the questionnaire was distributed, the statements in the questionnaire were tested for validity and reliability with pilot test of 35 students of bachelor degree of Faculty of Economics and Business University of Udayana. The results of validity test show that value of correlation coefficient of instrument equal to $r \geq 0,30$. This means that the research instrument can be said to be valid. The results of reliability test show that each question component has value of cronbach's alpha more than 0,60 , which means that all research instruments are indicated reliable.

In a certain time period, the distributed questionnaires received responses of 140 copies. Based that number, cooperatives with information about taxpayer identification number are 91 units which then become the sample of this research. Description of respondents is presented in table 1 below.

\subsection{Description of Research Variables}

Description of research variables aims to determine the average value, minimum value, maximum value and deviation of variables examined, specifically service quality, moral obligation, knowledge taxation, taxpayer intention and taxpayer's compliance. The result of the research variables is described in table 2 below.

Respondents tend to agree that cooperatives have knowledge of taxation. The average respondent's answer about the quality of tax services amounted to 3,02. The result indicates that respondents often feel the tax service officers provide services accurately in accordance with the promised. Tax authorities also provide services with quick response, knowledge and ability to serve in friendly and courteous manner. Average perceptions of respondents agree that if they do not fulfill tax obligations, they disobey ethics, principles of life, feel guilty and against the procedure of taxation. Respondents tend to have the intention of dutifully carrying out taxation obligations with the encouragement from the fiscus. The average trend of respondents states that taxpayers' beliefs to be obedient and compliant to tax responsibilities are driven by tax officials. 
Table 1: Description of Respondents Research

\begin{tabular}{|c|c|c|}
\hline & Number & Percentage $(\%)$ \\
\hline \multicolumn{3}{|l|}{ Type of Cooperative } \\
\hline a. Saving and loan cooperative & 70 & 77 \\
\hline b. Multi-purpose cooperative & 21 & 23 \\
\hline \multicolumn{3}{|l|}{ Age } \\
\hline a. 25-34 years & 19 & 21 \\
\hline b. $35-44$ years & 39 & 43 \\
\hline c. $\geq 45$ years & 33 & 27 \\
\hline \multicolumn{3}{|l|}{ Gender } \\
\hline a. Man & 76 & 84 \\
\hline b. Woman & 15 & 16 \\
\hline \multicolumn{3}{|l|}{ Education } \\
\hline a. High school & 2 & 2 \\
\hline b. Diploma & 10 & 11 \\
\hline c. Bachelor & 74 & 81 \\
\hline d. Master or higher & 5 & 6 \\
\hline \multicolumn{3}{|l|}{ Taxation Education } \\
\hline a. Tax brevet & 1 & 1 \\
\hline Course & 5 & 6 \\
\hline a. Training or counseling & 20 & 20 \\
\hline b. Seminar & 66 & 73 \\
\hline
\end{tabular}

Source: Data processed, 2018

Table 2: Description of Research Variables

\begin{tabular}{|l|l|l|l|l|l|}
\hline \multicolumn{1}{|c|}{ Variables } & N & \multicolumn{1}{|c|}{ Minimum } & \multicolumn{1}{|c|}{ Maximum } & \multicolumn{1}{|c|}{ Mean } & \multicolumn{1}{|c|}{ Standard Deviation } \\
\hline Taxation Knowledge & 91 & 1,00 & 3,93 & 2,98 & 0,87 \\
\hline Moral Obligation & 91 & 1,00 & 3,71 & 3,68 & 0,99 \\
\hline Service Quality of Tax & 91 & 1,04 & 3,84 & 3,02 & 0,87 \\
\hline Taxpayer's Intention & 91 & 1,00 & 3,95 & 2,98 & 0,87 \\
\hline Taxpayer's Compliance & 91 & 1,00 & 3,51 & 2,82 & 0,94 \\
\hline
\end{tabular}

Source: Data processed, 2018

\subsection{Hypotheses Testing Results}

Prior to hypotheses testing, initially assumption test is performed. Normality test result indicates that the data are normally distributed. Similarly with heteroscedasticity test result, it showed that there are no symptoms of heteroscedasticity. The result of the moderation regression test is presented in table 3 . 
Table 3: Result of Regression Moderation Analysis

\begin{tabular}{|l|l|l|l|l|}
\hline & $\begin{array}{c}\text { Unstandardized } \\
\text { Coefficients }(\beta)\end{array}$ & \multicolumn{1}{|c|}{$\begin{array}{c}\text { Standardized } \\
\text { Coefficients } \beta\end{array}$} & \multicolumn{1}{|c|}{$\mathrm{t}$} & $\begin{array}{c}\text { Significance } \\
\text { Value }\end{array}$ \\
\hline Constant & $-0,012$ & - & $-0,014$ & 0,980 \\
\hline TK & $-0,147$ & $-0,121$ & $-0,116$ & 0,908 \\
\hline MO & 0,900 & 0,833 & 0,762 & 0,448 \\
\hline SQ & $-0,496$ & $-0,407$ & $-2,665$ & 0,009 \\
\hline TI & 0,523 & 0,427 & 1,918 & 0,059 \\
\hline TK*TI & 0,024 & 0,134 & 0,078 & 0,938 \\
\hline MO*TI & $-0,167$ & $-1,002$ & $-0,589$ & 0,558 \\
\hline SQ*TI & 0,202 & 1,145 & 3,858 & 0,000 \\
\hline F Test & 135,216, sig. 0,000 & & \\
\hline Adjusted R & 0,913 & & & \\
\hline
\end{tabular}

Source: Data processed, 2018

Notation

$\begin{array}{ll}\text { TK } & \text { : Taxation Knowledge } \\ \text { MO } & \text { : Moral Obligation } \\ \text { SQ } & \text { : Service Quality } \\ \text { TI } & \text { : Taxpayer's Intention }\end{array}$

\subsection{The Competence of the Intention to Moderate the Influence of Taxation Knowledge on Taxpayer's Compliance}

Hypothesis $1\left(\mathrm{H}_{1}\right)$ reveals that taxpayer's intention enhances the influence of tax knowledge on taxpayer's behavior. The result of the analysis presents that intention does not moderate the influence of taxation knowledge on taxpayer's compliance, which means that $\mathrm{H}_{1}$ is not approved. Knowledge of taxation owned by the taxpayers and the intention of the taxpayers to perform the tax obligation do not initiate taxpayers to obey tax obligations.

Theory of planned behavior acknowledges that the immediate determinant of the individual's behavior is the intention to perform the behavior. Someone's intentions can be predicted through three things, namely their attitude, their subjective norms and the perception of behavioral control (Ajzen, 1991). A person's behavior to do or not to do something is strongly influenced by intention. Behavioral intention is an indication of a person's readiness to perform behavior, so the intention of behaving is a direct antecedent of behavior. Intention is the tendency of a person to choose to do or not to do a job and assumed as motivating factors that exist within the individual that determine behavior.

Respondents in this study are cooperative managements as proxy of cooperative taxpayer. The dutiful intention of the cooperative managements to carry out the obligations depends on the members of the cooperative. As a result, belief about the existence of aspects that support or inhibit the control beliefs and perceptions about how firmly supports and inhibits the perceived power, which is the most dominant in determine the intention of cooperative managements in doing or not doing an action.

\subsection{The Competence of the Intention to Moderate the Influence of Moral Obligations on Taxpayer's Compliance}

Hypothesis $2\left(\mathrm{H}_{2}\right)$ recognizes that taxpayer's intentions strengthen the impact of moral obligations on taxpayer's compliance. The result of the analysis shows that the intention does not moderate the moral obligation on taxpayer's compliance. This means that the high moral obligation followed by the intention to comply with the obligation of taxation cannot increase the cooperative taxpayer's compliance to fulfill their tax responsibilities.

Moral obligation is external factor of taxpayers in behaving obediently to pay taxes. Situational attribution is external motive that refers to the surrounding environment, which affects behaviors, such as social conditions, 
social values and community views. Compliance with tax obligation by cooperatives is eminently depend on their members. Cooperative managements' intentions are formed by normative beliefs, which consist of others normative beliefs and motivation to comply.

These results are in line with Wenzel (2014), Baron and Kenny (1997) and De-Juan, et al. (1994) which explained that the taxpayer's intention is not able to heighten someone's moral duty to accomplish taxation obligations in groups that behave disobediently because of social norms. Social norms are common practice that becomes the benchmark of behavior within a community group and certain territorial boundaries. Norms evolved along with the social agreements of their communities.

\subsection{The Competence of the Intention to Moderate the Quality of Service on Taxpayer's Compliance}

Hypothesis $3\left(\mathrm{H}_{3}\right)$ informs that the taxpayer's good intention increase the influence of the quality of tax service on taxpayer's compliance. The result of the analysis confirms that the intention is able to moderate the influence of the quality of tax service on taxpayer compliance. The more desirable the quality of service provided by the fiscus and assisted by taxpayer's obedient intentions to accomplish taxation obligations lead to more obedient cooperatives taxpayer to implement taxation obligations.

This result is in accordance with the theory of planned behavior which interprets that the immediate determinant of the individual's behavior is the intention to display the behavior. Someone's intention can be predicted through three main motives, namely their attitude toward things experienced, subjective norms possessed and the perception of behavioral control (Ajzen, 1991). A person's behavior to do or not to do something is firmly persuaded by the intention. The development of taxpayer's obedient behavior is strongly influenced by the taxpayer's compliant intention.

The outcome confirms the research conducted by Mustikasari (2007) which concluded that among the independent variables of attitude studied, perceived behavior control variable has the greatest impact on taxpayer intention to behave noncompliance. The taxpayer has the perception that if the facilities provided by the company are high or sufficient, then the tax noncompliance is low or vice versa. The existence of taxpayer's intention can expand the taxpayer's compliance behavior with the support of the quality of tax service provided.

\section{Conclusions and Suggestions}

Based on the discussion of research results, it can be concluded that the intention is not able to moderate the impact of taxation knowledge on taxpayer's compliance. Intention is also not competent to moderate the influence of moral obligation on taxpayer's compliance. This is likely to happen because the operational decision of the cooperative is determined in annual member meeting. However, the intention is adequate to moderate the effect of service quality on taxpayer's compliance. Excellent service quality followed by taxpayer's obedient intention caused taxpayer's compliance increased.

Further researchers are advised to use self-categorization theory that explains about a person's cognitive awareness of membership in a group to examine cooperatives taxpayer's compliance. The suggested respondents are members of cooperative as representatives of cooperative taxpayer to observe the consistency of research results.

\section{References}

Adiasa, N. (2013). Pengaruh Pemahaman Peraturan Pajak terhadap Kepatuhan Wajib Pajak dengan Moderating Preferensi (The Influence of Understanding of Tax Regulation on Taxpayer Compliance with Moderating Preference). Accounting Analysis Journal. Accounting Department Faculty of Economics, State University of Semarang

Ajzen, I \& Fishbein, M. (1969). The Prediction of Behavioral Intention in a Choice Situation. Journal of Experimental Social Psychology, 5, 400-416.

Ajzen, I. (1991). The Theory of Planned Behavior. Organizasional Behavior and Human Decision Process, 50, 179-211.

Baron, R. M. \& Kenny, D. A. (1986). The Moderator-Mediator Variabel Distiction in Social Psychological Research: Conceptual, Strategic, and Statistical Considerations. Journal of Personality and Social Psychology, 51, 1171-1182.

Bobek, D. \& Hatfield, R. C. (2003). An Investigation of the Theory of Planned Behavior and the Role of Moral Obligation in Tax Complience. Behavioral Research in Accounting, 15, 133. 
De-Juan, A., Lasheras, M. A. \& Mayo, R. (1994). Voluntary Tax Compliant Behavior of Spanish Income Tax Payers. Public Finance, 49, 90-105.

Erwin, H. (2009). Perilaku Kepatuhan Wajib Pajak Badan (Compliance Behavior of Corporate Taxpayer). Jurnal Ilmu Administrasi dan Organisasi, 16(2), 96-104.

Faudi, A. O. \& Mangoting, Y. (2013). Pengaruh Kualitas Pelayanan Petugas Pajak, Sanksi Perpajakan dan Biaya Kepatuhan Pajak Terhadap Kepatuhan Wajib Pajak UMKM (The Effect of Service Quality of Tax Officer, Tax Sanction and Compliance Cost of Tax to Compliance of SMEs Taxpayer). Journal Tax and Accounting Review, 1(1).

Hanno, D. \& Violette, G. (1996). An Analysis of Moral and Social Influences on Taxpayer Behavior. Behavior Research in Accounting, 8, 57-75.

Hardiningsih, P. \& Yulianawati, N. (2011). Faktor-Faktor yang Memengaruhi Kemauan Membayar Pajak (Factors Affecting Taxpayer's Willingness to Pay Taxes). Dinamika Keuangan dan Perbankan, 3(1), 126-142.

Heider. F. (1958). The Life of a Psychologist: an Autobiography. Lawrence. KS: University of Kansas Press. Downloaded December 30, 2016.

Hidayat, W. \& Nugroho, A. A. (2010). Studi Empiris Theory of Planned Behavior dan Pengaruh Kewajiban Moral pada Perilaku Ketidakpatuhan Pajak Wajib Pajak Orang Pribadi (Empirical Studies of Theory of Planned Behavior and Influence of Moral Obligations on Noncompliance Behavior of Personal Taxpayer). Jurnal Akuntansi dan Keuangan, 84(2).

Hoy, H. K. \& Tarter, C. J. (2004). Organizational Justice in Schools: No Justice Without Trust. International Journal of Educational Management, 18 (4), 250-259.

Ho, D. (2004). A Study of Hongkong Tax Compliance Ethics. International Business Research, 2(4), 145-151.

Masruroh, S. \& Zulaikha. (2013). Pengaruh Kemanfaatan NPWP, Pemahaman Wajib Pajak, Kualitas Pelayanan, Sanksi Perpajakan terhadap kepatuhan Wajib Pajak - Studi Empiris pada WPOP di Kabupaten Tegal (The Effect of Tax Identification Number Utilization, Taxpayer Understanding, Service Quality, Tax Sanction on Taxpayer Compliance - Empirical Study on Personal Taxpayer in Tegal Regency). Journal of Accounting, 2(4), University of Diponegoro.

Maulana. (2015). Relevansi Tax Ratio dengan Regulasi yang Ada (The Relevance of Tax Ratio with Existing Regulation). Available: http://mimaulana.Blog.com./2015/01/relevansi-tax-ratio-regulasi.html.

Mayer, R. C., Davis, J. H. \& Schoorman, F. D. (1995). An Integrative Model of Organizational Trust. Academy of Management Review, 30(3), 709-734.

Metia, R. O. (2015). Determinan Kepatuhan Wajib Pajak Badan dengan Niat sebagai Pemediasi dari perspektif Planned Behaviour Theory (Determinant of Corporate Taxpayer's Compliance with Intention as Mediator from the perspective of Planned Behavior Theory). Jurnal Bisnis dan Ekonomi, 22(185), 8595.

Murti, H., Wicaksono, Sondakh, Jullie, J. \& Sabijono, H. (2014). Pelayanan Fiskus dan Pengetahuan Perpajakan terhadap Kepatuhan Wajib Pajak Orang Pribadi di Kota Manado (Fiscal Service and Tax Knowledge on Personal Taxpayer Compliance in Manado City). Jurnal EMBA, 2(3), 389-398.

Mustikasari, E. (2007). Kajian Empiris Kepatuhan Wajib Pajak Badan di Perusahaan Industri Pengolahan di Surabaya (Empirical Study of Corporate Taxpayer's Compliance at Company of Processing Industry in Surabaya). Simposium Nasional Akuntansi X, Makassar.

Nurmantu, S. (2003). Pengantar Perpajakan (Introduction to Taxation). Jakarta: The Obor Foundation Group.

Parasuraman, A., Zeitham, A. \& Berry, L. (1988). Servqual: A Multiple-Item Scale for Measuring Consumer Perception of Service Quality. Journal of Retailing. 64(1). Available: http:/areas.kenan-flagler.unc.edu.

Pranadata, I. G. P. (2014). Pengaruh Pemahaman Wajib Pajak, Kualitas Pelayanan Perpajakan, dan Pelaksanaan Sanksi Pajak terhadap Kepatuhan Wajib Pajak Orang Pribadi pada Kantor Pelayanan Pajak Pratama Batu (The Effect of Taxpayer Understanding, Quality of Tax Service and Implementation of Tax Sanction against Individual Taxpayer Compliance at Batu Tax Office). Jurnal Mahasiswa FEB, 2(2).

Pranata, P. A. (2015). Pengaruh Sanksi Perpajakan, Kualitas Pelayanan dan Kewajiban Moral pada Kepatuhan Wajib Pajak (The Effect of Tax Sanctions, Service Quality and Moral Obligation on Taxpayer Compliance). E-Jurnal Akuntansi Universitas Udayana, 10(2), 456-473.

Razman, A. A. L. (2015). Tax Literacy among Tax Payers: Evidence from Malaysia. JAAI, 9(1), 1-13.

Richardson, G. (2006). Determinants of Tax Evasion: A Cross Country Investigation. Journal of International Accounting, Auditing and Taxation, 15, 150-160.

Robbins, S. P. (1999). Organization Behavior, Concepts, Controversies, Application. (7 ${ }^{\text {th }}$ Ed.). Englewood Cliffs \& PT. Prenhallindo, Jakarta. 
Rustiyaningsih, S. (2011). Faktor-Faktor yang Memengaruhi Wajib Pajak (Factors Affecting Taxpayers). Widya Warta, 2.

Siregar, Y. A., Saryadi \& Listyorini, S. (2012). Pengaruh Pelayanan Fiskus dan Pengetahuan Perpajakan terhadap Kepatuhan Wajib Pajak - Studi Empiris terhadap Wajib Pajak di Semarang Tengah (The Influence of Fiscal Service and Tax Knowledge of Taxpayer's Compliance - Empirical Study of Taxpayers in Central Semarang). Jurnal Ilmu Adminitrasi Bisnis. University of Diponegoro.

Wenzel, M. (2004). An Analysis of Norm Processes in Tax Complience. Journal of Economic Phychology, 25, 213-218.

Widayati \& Nurlis. (2010). Faktor-Faktor yang Memengaruhi Kemauan untuk Membayar Pajak Wajib Pajak Orang Pribadi yang Melakukan Pekerjaan Bebas - Studi Kasus Pada KPP Pratama Gambir Tiga (Factors Affecting the Willingness of Personal Taxpayer who Conducting Free Work to Pay Taxes - A Case Study at Gambir Tiga Tax Office). Simposium Nasional Akuntansi XIII, Purwokerto.

Winerungan, O. L. (2013). Sosialisasi Perpajakan, Pelayanan Fiskus dan Sanksi Perpajakan terhadap Kepatuhan WPOP di KPP Manado dan KPP Bitung (Socialization of Taxation, Fiscal Services and Tax Sanctions on Personal Taxpayer's Compliance at Tax office in Manado and Bitung). Jurnal EMBA, 960-970.

Zulaikha \& Nugroho. (2012). Faktor-Faktor yang Mempengaruhi Kemauan untuk Membayar Pajak dengan Kesadaran Membayar Pajak sebagai Variabel Intervening - Studi Kasus Wajib Pajak Orang Pribadi yang Melakukan Pekerjaan Bebas yang Terdaftar di KPP Pratama Semarang Tengah Satu (Factors Affecting the Willingness to Pay Taxes with Awareness of Paying Taxes as Intervening Variables - Case Study of Personal Taxpayer who Conducting Free Work Registered in Semarang Tengah Satu Tax Office). Journal of Accounting, 1(2). 